\title{
THE ROLE, INDEPENDENCE AND ACCOUNTABILITY OF THE AUDITOR GENERAL: A COMPARATIVE CONSTITUTIONAL ANALYSIS
}

\author{
John Hatchard*
}

'The ally of the People'1

'Be you ever so high, the law is above you'2

\begin{abstract}
The Auditor General plays a key role in the constitutional framework that is designed to support good governance. This article critically reviews the constitutional position of the Auditor General. It assesses the extent to which, in practice, office-holders enjoy the necessary individual and institutional independence and security of tenure to enable them to carry out their constitutional mandate, especially in the face of efforts by some political leaders and senior public officials ("politically exposed persons' (PEPs)) to abuse their position through acts of corruption and misuse of public office. It also explores the effectiveness of the support and accountability mechanisms for Auditors General. In doing so, the article reviews the position of the Auditor General in the constitutions of a number of Anglophone African states.

Keywords: Auditor General; constitutional role of; individual and institutional independence of; politically exposed persons; Anglophone African constitutions.
\end{abstract}

\section{INTRODUCTION}

The Constitution is the supreme law of a state ${ }^{3}$ and as a former Chief Justice of South Africa, Justice Ismail Mohammed, once observed, it is not simply a document which mechanically defines the structures of government and the relations between the government and the governed, but it is:

\footnotetext{
* Professor of Law, Buckingham Law School; Co-Director, University of Buckingham Centre for Extractive Energy Studies.

1 Transparency International (TI Kenya) v Attorney General [2018] eKLR [5] (Mwita J).

2 Gouriet v Union of Post Office Workers [1977] 1 QB 729, 762 (Lord Denning) quoting the words of Thomas Fuller.

3 See for example the African Charter on Democracy, Elections and Governance, article 10 which provides that 'State Parties shall entrench the principle of the supremacy of the Constitution in the political organization of the State'.
} 
[A] mirror reflecting the national soul, the identification of the ideals and aspirations of a nation; the articulation of the values binding its people and disciplining its government. ${ }^{4}$

The words 'disciplining its government' emphasise that whilst constitutional office-holders enjoy significant powers and privileges, they are bound to act in accordance with its 'good governance' values that include integrity, transparency and accountability. ${ }^{5}$

The legislature traditionally plays an oversight role over the executive in such matters. In reality this has proved of limited value, not least due to the dominance of the ruling party in many countries. Thus modern Constitutions now often enshrine a range of independent watchdog bodies each enjoying a distinct mandate designed to secure good governance. For example, offices of the ombudsman investigate complaints from members of the public into alleged maladministration by public officials, anti-corruption commissions work to prevent corruption in the public service whilst human rights commissions provide a vehicle for individuals to seek redress against public officials for a breach of their constitutional rights. Added to this list is the Auditor General whose constitutional mandate is to audit and to report annually to the legislature on the use of public funds.

Including the Auditor General in this framework of 'state institutions supporting constitutional democracy' ${ }^{6}$ emphasises that this is not an isolated and somewhat remote office but part of a scheme that is designed to ensure that the good governance values enshrined in the Constitution apply to the daily administration of the country at all levels. In essence, such institutions form an additional branch of government.

This article critically reviews the constitutional position of the Auditor General. It assesses the extent to which, in practice, the office-holders enjoy the necessary individual and institutional independence and security of tenure to enable them to carry out their constitutional mandate, especially in the face of efforts by some political leaders and senior public officials (hereinafter "politically

4 State v Acheson [1991] (2) SA 805 (Nm) 813, A-B. See also the comments of the Supreme Court of Ghana in Taffour v Attorney General [1980] GLR 637, 647-48.

5 See for example the Constitution of Kenya, article 10 and the Preamble to the Constitution of Zimbabwe.

6 A phrase used to describe such institutions in the Constitution of South Africa 1996, ch 9. 
exposed persons ${ }^{77}$ (PEPs)) to abuse their position through acts of corruption and misuse of public office. It also explores the effectiveness of the support and accountability mechanisms for Auditors General. In doing so, the article reviews the position of the Auditor General in the Constitutions of a number of Anglophone African states (collectively referred to as the 'Constitutions'). ${ }^{8}$ These have been chosen as most are based on the Westminster export model Constitution and, although much amended or replaced, still share a similar structure.

The article is divided into the following parts. Part 1 explores the constitutional role of the Auditor General in maintaining transparency and accountability in public finances whilst Part 2 considers the basic provisions for developing an effective auditing role. Parts 3 and 4 then analyse the constitutional provisions in support of individual and institutional autonomy of the office and office-holder. Part 5 examines the mechanisms to support and oversee the work of the Auditor General whilst Part 6 assesses the constitutional provisions for the removal of the Auditor General. Part 7 then provides a conclusion.

\section{PART 1: THE CONSTITUTIONAL ROLE OF THE AUDITOR GENERAL IN MAINTAINING TRANSPARENCY AND ACCOUNTABILITY IN PUBLIC FINANCES}

\section{i) The challenge of PEPs}

The history of corruption and the looting of state assets by African PEPs is a long and depressing one. The well-documented case of Sani Abacha highlights to challenge facing many states. Abacha was the Head of State in Nigeria (and thus a PEP) who had seized power in a military coup in 1993. Between 1992 and 1998 he and his family accumulated wealth at an extraordinary rate, including extracting huge sums from the Central Bank of Nigeria by raising a series of demands for

\footnotetext{
7 For the purposes of this article, the term 'PEPs' refers to 'individuals who are or have been entrusted domestically with prominent public functions, for example Heads of State or of government, senior politicians, senior government, judicial or military officials, senior executives of state owned corporations, important political party officials': see Financial Action Task Force International Standards on Combating Money Laundering and the Financing of Terrorism \& Proliferation: The FATF Recommendations (2012) Glossary.

8 Examples are drawn from Ghana, Kenya, Malawi, Namibia, Nigeria, South Africa, Uganda, Zambia and Zimbabwe. However, it is not the intention of the article to consider the constitutional position of the Auditor General in each jurisdiction.
} 
funds to meet spurious national security needs. ${ }^{9}$ Frederick Chiluba, the then President of Zambia, later used the same 'national security' tactic to loot state funds. ${ }^{10}$ Other well-known cases involve theft of state development funds by Diepreye Alamieyeseigha, a former state governor of Bayelsa State in Nigeria, ${ }^{11}$ the inflation of the price of government contracts by Mahmoud Thiam, a former Minister of Mines in Guinea ${ }^{12}$ and the widespread abuse of public funds by Teodoro Obiang, the son of the President of Equatorial Guinea. As a result, countless people throughout Africa have been (and remain) victims of a breakdown of basic infrastructure and public services.

There are ongoing efforts recover the proceeds of corruption that were laundered abroad and for their return to the victim states, albeit this remains work in progress. Whilst such efforts are laudable, less attention has been paid to preventing such criminality by PEPs in the 'victim' states themselves. What is striking about each of the above cases is the seeming lack of any accountability of the PEPs for their actions due to the failure of (or lack of) effective constitutional accountability mechanisms. This is not surprising given that PEPs are the most powerful political individuals in any state and can 'control the controls'. For example, by preventing, or undermining, domestic investigations into corruption and money laundering and controlling the operation of international cooperation mechanisms designed to trace the proceeds of corruption. ${ }^{13}$ They are often assisted in their criminality by powerful banking and other financial institutions through which the proceeds of corruption are laundered as well as by imaginative and inventive professional money launderers. ${ }^{14}$

The task of preventing such criminality by PEPs is therefore a daunting one but the suitably adapted words of Lord Denning (quoted above) suggest how this can be done: 'Be you ever so high, the Constitution is above you'. Thus the

9 Much of the activity of the Abacha family members is described in the case of Companie Naga d'Importation SA v Australia and NewZealand Banking Group Queen's Bench Division (Comm) 27 February 2001 (unreported). Upheld on appeal [2003] EWCA Civ 1101.

10 The facts are set out in Attorney General of Zambia v Meer Care and Desai [2007] EWHC 952 (Peter Smith J). See also the discussion below.

11 See Nigeria $v$ Santolina Investment Corp [2007] EWHC 3053 (QB).

12 The facts appear in United States of America v Thiam: Government's Sentencing Memorandum 25 August 2017 <www.justice.gov/criminal-fraud/fcpa/cases/mahmoudthiam $>$ accessed 3 October 2018.

13 John Hatchard, Combating Corruption: Legal Approaches to Supporting Good Governance and Integrity in Africa (Edward Elgar 2014) 279 et seq.

14 See generally the report by the Financial Action Task Force Professional Money Laundering (FATF 2018). 
challenge is to develop and maintain effective constitutional accountability mechanisms that are capable of holding PEPs to account for their use (or abuse) of public finances. This is the onerous and challenging role played by the Auditor General.

\section{ii) The 'ally of the people'}

Article 10 of the United Nations Convention Against Corruption (UNCAC) emphasises the need for each State Party to take the necessary measures 'in accordance with the fundamental principles of its domestic law', to 'enhance transparency in its public administration, including with regard to its organisation, functioning and decision-making processes, where appropriate'. This includes taking steps to ensure fiscal integrity, transparency and accountability in government and the public service. Further the UNCAC Conference of States Parties (the CoSP) has acknowledged that 'efficient, accountable and transparent service delivery is one of the key components in building an anti-corruption environment in the public sector'. ${ }^{15}$ The key role played by Auditors General in enhancing this goal is echoed in article IX of the Commonwealth Principles ${ }^{16}$ which were endorsed by Commonwealth Heads of Government in 2003.

As Yilmaz and Beris have pointed out, accountability addresses a number of elements including providing for transparency in the use of public funds and public accessibility to such information. ${ }^{17}$ However, the key to accountability is 'control'. This requires an independent audit body or bodies to ensure fiscal integrity, i.e. that the powers of such office-holders are not abused or misused and that there is accountability for retaining 'sound and transparent public expenditure and financial management systems'. ${ }^{18}$ This has the dual purpose of both encouraging

15 CoSP Resolution 6/6 2015, follow-up to the Marrakech declaration on the prevention of corruption (2015), Preamble. All the African states discussed in this article are state parties to the UNCAC.

16 Commonwealth (Latimer House) Principles on the Accountability of and Relationship between the Three Branches of Government. Article IX states 'Independent bodies such as ... Auditors General ... and similar oversight institutions can play a key role in enhancing public awareness of good governance and rule of law issues'.

17 Serder Yilmaz and Yakup Beris 'Good Governance and the Emergence of a New Accountability Agenda' in Gabor Peteri (ed), Finding the Money: Public Accountability and Service Efficiency through Fiscal Transparency (Local Government and Public Service Reform Initiative, Open Society Initiative, 2008) 30.

18 Ibid. 
'ethical behaviour by making unethical behaviour hard to accomplish and easy to detect' and helping to bring to light any abuse of power. ${ }^{19}$

The position of Auditor General is enshrined in all the Constitutions ${ }^{20}$ and as the supreme audit authority, the office-holder has responsibility for auditing on an annual basis the accounts of all government and other state institutions, ${ }^{21}$ publishing an annual report and submitting this to the legislature for scrutiny and debate. Thus the office-holder is the key constitutional figure in overseeing the proper use of public resources and, if necessary, of publicly exposing any abuse of public funds. This role is neatly explained by Mwita $\mathrm{J}$ in Transparency International (TI Kenya) v Attorney General: ${ }^{22}$

... [T] he Auditor General is an ally of the people. While Parliament is the peoples' representative, the Auditor General provides Parliament with accurate and independently derived audit information on state organs and public bodies expenditure [and] thus ensures that there is public sector accountability. ${ }^{23}$

The effective performance of this responsibility is neatly highlighted in two cases. In 2017 a report by the Zambian Auditor General alleged that officials in the Ministry of Education had diverted donor funds provided for poverty alleviation projects into off-shore bank accounts through the use of shell companies. This revelation led to the United Kingdom, Ireland, Finland and Sweden suspending aid for the project to Zambia whilst a number of senior PEPs were dismissed by the Zambian President, Edgar Lungu. ${ }^{24}$

In 2013, forensic investigations by Malawi's Auditor General uncovered the fact that significant amounts of government money had been misappropriated by a number of PEPs in what became known as the 'Cashgate scandal'. This quickly led to a major investigation (which is ongoing) which revealed that 'some highly and strategically placed politicians and public/civil servants conspired to defraud

19 Ibid.

20 Thus a statutory provision referring to the Auditor General as the 'statutory' head of the office violates the Constitution: see the TI Kenya (n 1) [83].

21 See for example Constitution of Kenya, article 226(3).

22 TI Kenya (n 1) [5]. The case is considered in detail below.

23 In the case of Re the Matter of the Independent Electoral and Boundaries Commission of Kenya [2011] eKLR, the Supreme Court of Kenya also helpfully described independent Commissions and bodies such as the Office of the Auditor General as 'people's watchdogs': [59].

24 BBC News report dated 18 September 2018. 
the Government of Malawi of large sums of money'. ${ }^{25}$ As Mr Justice Kapindu neatly put it:

In September 2013, gates to what was meant to be a clandestine and non-detectable criminal syndicate of fraudsters and money launderers were flung open. Information revealing an unprecedented fiscal scandal gradually unfolded in a manner an unsuspecting observer would have been forgiven to think was a masterfully scripted piece of fiction. It was a shocking reality. Billions of Kwacha had been embezzled from the national fiscus by some unscrupulous people. ${ }^{26}$

\section{PART 2: TOWARDS AN EFFECTIVE AUDITING ROLE}

Requiring Auditors General to 'exercise their powers and perform their functions without fear, favour or prejudice' is a constitutional imperative. ${ }^{27}$ Yet the Zambian and Malawian cases illustrate the point made by the Constitutional Court of South Africa that the work of the Auditor General 'inherently entails the investigation of sensitive and potentially embarrassing affairs of government', ${ }^{28}$ and those of PEPs in particular. In order to enable Auditors General to carry out their constitutional role of effective public sector auditing, eight Core Principles (the Core Principles) were recognised in the Mexico Declaration on Supreme Audit Authority Independence (the Mexico Declaration). ${ }^{29}$ These cover issues relating to independence, security of tenure, investigative powers, and unrestricted access to information. These Core Principles are noted throughout this article. ${ }^{30}$

\section{i) Establishing and maintaining an independent office}

Core Principle 2 states that the independence of the Auditor General is an essential requirement for proper public sector auditing. This emphasises the fundamental

\footnotetext{
25 Republic v Lutepo [2015] MWHC 491(High Court of Malawi) (Kapindu J) [7].

26 Lutepo (n 25 [1]).

27 Constitution of South Africa 1996, article 181(2).

28 Quoting from Ex parte Chairperson of the Constitutional Assembly: In re Certification of the Constitution of the Republic of South Africa, 1996 [1996] ZACC 26, 1996 (4) SA 744 (CC), 1996 (10) BCLR 1253 (CC) (First Certification) [163].

29 Agreed at the XIX Congress of the International Organization of Supreme Audit Authorities (INTOSAI).

30 The African Organization of Supreme Audit Institutions collaborates with the INTOSAI.
} 
requirement of enshrining the independence of the office and office-holder in the Constitution and is discussed in Part 4 below.

\section{ii) Providing 'a sufficiently broad mandate ${ }^{31}$}

In carrying out their constitutional role effectively, Auditors-General must be empowered to audit all state bodies or public entities. In some Constitutions, the specific bodies and entities are listed..$^{32}$ For example, the Article 187(2) of the Constitution of Ghana provides:

The public accounts of Ghana and of all public offices, including the courts, the central and local government administrations, of the Universities and public institutions of like nature, of any public corporation or other body or organisation established by an Act of Parliament shall be audited and reported on by the Auditor-General.

Similarly, Article 188(1) of the Constitution of South Africa provides:

The Auditor-General must audit and report on the accounts, financial statements and financial management of (a) all national and provincial state departments and administrations; (b) all municipalities; and (c) any other institution or accounting entity required by national or provincial legislation to be audited by the Auditor-General.

A key to a successful audit is unrestricted access to all relevant documentation or premises. ${ }^{33}$ This is emphasised in Article 187(3) of the Constitution of Ghana:

... [T]he Auditor-General or any person authorised or appointed for the purpose by the Auditor-General shall have access to all books, records, returns and other documents relating or relevant to those accounts.

Access to sensitive 'national security' information provides a particular challenge for, as noted earlier, there are several examples where PEPs have stolen state assets under the cover of spurious 'national security' needs. This focuses attention on the extent to which Auditors General enjoy in practice the

\footnotetext{
31 Core Principle 3.

32 For a useful discussion on the scope of the Auditor General's powers, see Khumalo $v$ Auditor General [2013] SZHC 56 (High Court of Swaziland).

${ }^{33}$ Core Principle 4 refers to 'unrestricted access to information'.
} 
'unrestricted access to information' required for carrying out their functions, ${ }^{34}$ including that relating to expenditure on 'national security'. This was the focus in the High Court of Kenya case of Transparency International (TI Kenya) $v$ Attorney General. ${ }^{35}$

\section{iii) The TI case}

In this important case, the petitioners submitted that a number of sections of the Public Audit Act 2015 (PAA) were unconstitutional both in purpose and effect as they tended to 'interfere with the independence and mandate of the Auditor General, an independent constitutional office'. ${ }^{36}$ The Constitution of Kenya provides, amongst other things, that the Auditor General is 'subject only to the Constitution and the law and independent and not subject to direction or control by any person or authority'. ${ }^{37}$ Further, that in carrying his/her constitutional mandate the 'Auditor-General may audit and report on the accounts of any entity that is funded from public funds' (my emphasis) and 'An audit report shall confirm whether or not public money has been applied lawfully and in an effective way'. ${ }^{38}$

One provision of the PAA that was challenged was section 40. Mwita J noted the section required the Auditor General 'to hold a pre-audit meeting at the highest level to agree on areas to audit and the appropriate audit approach when auditing national security organs and even allows vetting of officers to conduct the audit'. ${ }^{39}$ In addition, he noted that section 42 of the PAA barred the Auditor General from questioning government policy objectives during audits.

In an impressive and thoughtful judgment, Mwita $\mathrm{J}$ declared these sections unconstitutional. Having discussed the constitutional provisions relating to the independence of the Auditor General he continued:

Flowing from the exposition above, it leaves no doubt on the unconstitutionality of sections 40 and 42 of the Act.... The Auditor General has a constitutional obligation under Article 229(4)(h) to audit and report on the accounts of state organs public bodies and any entity funded by public money. This cannot be done if the Auditor General has to seek permission by holding meetings with

\footnotetext{
34 Core Principle 4.

35 Petition 388 of 2016; [2018] eKLR.

36 TI Kenya (n 1) [77].

37 article $249(2)$.

38 articles 229(5), (6).

39 TI Kenya (n 1) [118].
} 
higher authorities as proposed by section 40 before carrying out the audit. Subjecting officers to vetting before audit would leave room for state organs and public bodies to decide who to audit them.

As regards the limitations imposed in section 42, as Mwita $\mathrm{J}$ explained:

The Auditor General cannot also confirm the viability of the policy objectives funded by the people of Kenya when section 42 suggests that he should not question policy objectives funded by the people. This has the effect of stifling his independence. A statute cannot seek to impose conditions on the Auditor General's audit approaches when the Constitution gives him mandate to do his work without direction or control from any person or authority. This violates national values and principles of governance including integrity, transparency and accountability in Article 10 and financial openness in Article 201 of the Constitution. (emphasis added) ${ }^{40}$

It followed that the wide constitutional mandate of the Auditor General included the right to scrutinise spending by all entities that were publicly funded and this included the National Intelligence Service, the Kenya Defence Force and the National Police Service.

Given the vast sums of money lost by states when national security becomes a veil for corrupt activity by PEPs, requiring transparency in spending on 'national security' is a milestone in seeking to address such criminality ${ }^{41}$ Understandably public confidence and trust in national security financing requires an appropriate balance between secrecy and transparency. This emphasises the importance of having a demonstrably independent appointee holding the office of Auditor General.

The case also emphasises the supremacy of the Constitution. Thus any attempt to undermine or restrict the constitutional role and powers of the Auditor General by legislation must be declared unconstitutional. It also recognises the role of the Auditor General as the 'ally of the people' and emphasises the role of the

40 TI Kenya (n 1) [118-19]. Constitution of Kenya, article 10 states: 'The national values and principles of governance in this Article bind all State organs, State officers, public officers and all persons' when carrying out their public functions. These include 'good governance, integrity, transparency and accountability'.

${ }^{41}$ For a helpful discussion on this area, see Transparency International (UK) report 'Out of the Shadows: Promoting Openness and Accountability in the Global Defence Industry' (2016) < https://ti-defence.org/wp-content/uploads/2018/09/Out_of_the_Shadows_WEB3. pdf $>$ accessed 25 October 2018. 
office-holder as an independent watchdog body. Further it demonstrates the role of civil society organisations in supporting and publicising the work of such constitutional bodies. It is of interest that the locus standi of the petitioners in the TI case was not questioned.

In Attorney General for Zambia v Meer Care and Desai ${ }^{42}$ Peter Smith J in the High Court of England and Wales was satisfied that the Auditor General in Zambia had the power to scrutinise defence procurement contracts. The position in the other African jurisdictions is not clear. Perhaps it is time for the civil society organisations in those jurisdictions to follow the lead of TI Kenya and test the matter in the courts.

\section{PART 3: CONSTITUTIONAL PROVISIONS IN SUPPORT OF INDIVIDUAL AND INSTITUTIONAL AUTONOMY I: THE APPOINTMENT PROCESS}

As with other oversight bodies, it is essential that the appointment of the Auditor General is made through a demonstrably fair and transparent procedure. This is essentially a confidence-building exercise for government, public officials, citizens, civil society and donors alike in the integrity, independence and competence of the appointee. Whilst considerable attention has been paid in modern Constitutions to the appointment process of members of other oversight bodies, the position of the Auditor General often remains unsatisfactory. There are three key issues here: (i) the qualifications for appointment; (ii) the nomination process; and (iii) the appointment process itself.

\section{i) Qualifications for appointment}

Curiously, few of the Constitutions lay down any specific qualifications for appointment. In South Africa the Auditor General must be '... a fit and proper person to hold that office. Specialised knowledge of, or experience in, auditing, state finances and public administration must be given due regard in appointing the Auditor-General'. ${ }^{43}$ More specifically, in Kenya the Auditor General must 'have extensive knowledge of public finance or at least ten years' experience in auditing or public finance management'. ${ }^{44}$ Such a background is surely a prerequisite for any such appointment.

\footnotetext{
$42 \mathrm{n} 10$.

43 Section 193(3).

44 Constitution of Kenya, article 229(2).
} 


\section{ii) Nominating the candidate for appointment}

In most of the Constitutions it is the President who has the sole power to nominate the candidate. ${ }^{45}$ There is no justification for this position for it does not bring with it any confidence in the independence of the President's choice. A preferable approach is for the nomination to emanate from a separate body. This is the position in Nigeria ${ }^{46}$ and Namibia ${ }^{47}$ where the recommendation for appointment is made by the Federal Civil Service Commission and Public Service Commission respectively. Of course, it raises the question as to the independence of the Commissions themselves. Thus in Nigeria the Commission comprises a Chairman and not more than fifteen other members, who 'shall, in the opinion of the President, be persons of unquestionable integrity and sound political judgment'. ${ }^{48}$ In Namibia there is a stronger formulation. The Public Service Commission consists of a 'chairperson and not less than three nor more than six other persons nominated by the President and appointed by the National Assembly by resolution'. It 'shall be independent and act impartially'. ${ }^{49}$ There is no provision for any public involvement in the nomination process.

\section{iii) The appointment process}

The Constitutions contain a variety of procedures concerning the appointment process albeit with the legislature being involved in most jurisdictions. ${ }^{50}$ The most common procedure is for the President to appoint the Auditor General 'with the approval of the legislature"51 or 'subject to ratification' by the legislature..$^{52}$ This is a weak approach for the President is able to hand-pick their chosen candidate and then have the (normally) cooperative legislature

\footnotetext{
45 It is recognised that separate legislation may make provision for the selection process but it is argued that the appointment process is so fundamental that it must be enshrined in the Constitution to avoid any weakening of the procedure by subsequent legislation.

46 Constitution of Nigeria, section 86(1); Constitution of Namibia, article 127(1).

47 Constitution of Namibia, article 32(3)(i).

48 Constitution of Nigeria, $3^{\text {rd }}$ sch, para 10.

49 Constitution of Namibia, article 112(3). There is also a concern that the bodies making the recommendation are themselves subject to scrutiny by the Auditor General.

${ }^{50}$ In Ghana, article 70(1) of the Constitution provides: 'The President shall, acting in consultation with the Council of State, appoint ... the Auditor-General'. Given the presidential influence over the Council, this does not hold out strong hopes of an independent assessment of the matter.

51 For example in Namibia, Uganda, Zimbabwe and Kenya.

52 For example in Zambia.
} 
rubber-stamp the appointment by a simple majority. A stronger formulation is found in the Constitution of Malawi which provides that the appointment must be confirmed by the National Assembly by a majority of the members present and voting. ${ }^{53}$

In South Africa the support of at least 60 per cent of the members of the National Assembly is required. ${ }^{54}$ The rationale for such a requirement was noted by Mogoeng CJ in the Constitutional Court of South Africa in Helen Suzman Foundation $v$ President of the Republic of South Africa and Others: ${ }^{55}$

... [I]n the case of the Public Protector and Auditor-General the Constitution goes further, requiring that the recommendation be approved by a supermajority. These are the two institutions of accountability whose gaze ... is fixed firmly on the political branches; their task 'inherently entails investigation of sensitive and potentially embarrassing affairs of government ${ }^{56}$.

In Nigeria the appointment is subject to confirmation by the Senate ${ }^{57}$ which has the power to reject a presidential nomination. ${ }^{58}$ The role of the Auditor General as the 'ally of the people' raises the issue of public involvement in the appointment process. Regrettably, the only Constitution to address this important point is the Constitution of South Africa where section 194(6) provides that the 'involvement of civil society in the recommendation process [for the appointment of the Auditor General] may be provided for as envisaged in section 59(1)'. Section 59(1) states that 'the National Assembly must ... facilitate public involvement in the legislative and other processes of the Assembly and its committees'.

All of the Constitutions provide that the President formally appoints the Auditor General. This is unexceptional. However, the current procedure for appointment in most Constitutions arguably provides the President with far too

\footnotetext{
53 Section 184(1).

54 article 193(5).

55 [2014] ZACC 32, 2015 (1) BCLR 1 (CC), 2015 (2) SA 1 (CC) [159].
}

56 Quoting from Ex parte Chairperson of the Constitutional Assembly: In re Certification of the Constitution of the Republic of South Africa, 1996 (n 28) [163].

57 Constitution of Nigeria, section 86(1).

58 In December 2016, the Senate rejected the nomination by President Buhari of Ibrahim Magu as the Chairman of the Economic and Financial Crimes Commission based on an adverse 'security report' from the State Security Service. The power of the Senate to do so was upheld by the Abuja Federal High Court in Ojamo $v$ Attorney General of the Federation of Nigeria (2018 unreported). 
much influence, especially given the perceived weakness of the legislature in many jurisdictions. If the Auditor General is to be, and be seen by the public as being, an 'ally of the people' whose mission as an independent constitutional office-holder is to protect public finances, then there must be confidence in the transparency and reliability of the appointment process.

Arguably the objective is the same as with judicial appointments: i.e. to appoint 'a professionally competent person of proven integrity' with candidates being drawn from as wide a pool as possible. It follows that restricting the nomination process to the President is unacceptable and that there should be an opportunity for the public involvement in the process.

\section{PART 4: CONSTITUTIONAL PROVISIONS IN SUPPORT OF INDIVIDUAL AND INSTITUTIONAL AUTONOMY II: ADMINISTRATIVE AND FINANCIAL AUTONOMY}

Article 187(7) of the Constitution of Ghana neatly encapsulates the independence of the Auditor General:

'In the performance of his functions under this Constitution or any other law the Auditor-General ... shall not be subject to the direction or control of any other person or authority....59

The office and office-holder must therefore be entirely independent of government ${ }^{60}$ including the Public Service Commission (PSC) ${ }^{61}$ a key point as the PSC itself is subject to the audit process.

\section{i) Financial autonomy}

Core Principle 8 states that an Auditor General requires: 'Financial and managerial/ administrative autonomy and the availability of appropriate human, material and monetary resources'. This means that the administrative expenses of the office of

\footnotetext{
59 TI Kenya (n 1) [117]: Mwita J also noted that 'as the [holder] of an independent office, he is subject only to the Constitution and the law and is not subject to direction or control of any person or authority'.

60 The point was also emphasised in Thomas $v$ Attorney General of Trinidad and Tobago [1982] AC 113, 124 (Lord Diplock), where he observed that the purpose of such provisions was to insulate members from political interference exercised directly upon them by the government of the day.

61 A point specifically made in the Constitution of Namibia, article 127(3).
} 
the Auditor General must be charged on the Consolidated Fund. ${ }^{62}$ It also follows that the recruitment of staff and other staffing matters are solely a matter for the office-holder and thus the Public Service Commission plays no part in the process. In essence, ' $\ldots$ the workings of the Auditor General including recruitment and discipline cannot be subject to the Public Service Commission or any other authority' and any provision to the contrary violates such independence. ${ }^{63}$

The importance of the point is illustrated by the fact that in several countries 'advisory boards' have been established which threaten this independence. For example, in Kenya, the Audit Advisory Board (AAB) was established by the Public Audit Act 2015, its principle function being to 'advise the Auditor General on how to discharge his/her mandate under the Constitution'. In the TI case, Mwita $\mathrm{J}$ highlighted the independence of the Auditor General which was enshrined in article 249(2) and which provided that the office-holder is not under 'the direction or control of any person or authority'. ${ }^{64}$ The role of the AAB was therefore an 'interference with his institutional and individual independence' which altered the 'constitutional architecture of the independent office of the Auditor General and violated article 249(2) ${ }^{6}{ }^{65} \mathrm{He}$ therefore had no hesitation in declaring the provision inconsistent with the Constitution of Kenya. This is a most welcome ruling and should encourage civil society organisations in other jurisdictions to seek judicial review of the constitutionality of any domestic legislation adversely affecting the office of the Auditor General.

For Ghana the matter is more complex in that the Audit Service Board (ASB) is established by Article 189 of the Constitution of Ghana. Its membership comprises (a) a chairman and four other members appointed by the President, acting in consultation with the Council of State; (b) the Auditor General; and (c) the Head of the Civil Service or his representative. ${ }^{66}$ Its functions directly impact on the independence of the Auditor General. Articles 189(2) and (3) provide that 'the appointment of officers and other employees in the Audit Service, other than the Auditor General, shall be made by the Audit Service Board, acting in consultation with the Public Services Commission'. Articles 189(2) and (3) also provide that the ASB 'shall, acting in consultation with the Public Services Commission ... determine the terms and conditions of service

62 This includes all salaries, allowances, gratuities and pensions payable to or in respect of persons serving in the Audit Service: see for example article 187(14) Constitution of Ghana.

63 TI Kenya (n 1) [88] (Mwita J). See also [101].

64 TI Kenya (n 1) [114].

65 TI Kenya [116] (Mwita J).

66 article 189(1). 
of officers and other employees in the Audit Service'. These provisions constitute a direct interference with the institutional and individual independence of the Auditor General and are inconsistent with article 187(7) of Constitution of Ghana which was noted earlier. This is another fruitful issue for a civil society organisation to take up in the courts.

\section{ii) Security of tenure}

Core Principle 2 states that Auditors General must enjoy security of tenure. Inevitably, this is linked to the term of office for the incumbent. Here the Constitutions vary considerably. The majority provide for a fixed, non-renewable term with the length varying between five years and twelve years. In Namibia the Auditor General holds office for five years but is eligible for re-appointment. ${ }^{67}$

The danger of a fixed-term appointment is that the experience, expertise and public confidence in the office-holder is likely to be lost. Further, given that there is no constitutional provision relating to the time-frame for appointment of a new office-holder, there may be a lengthy hiatus (deliberate or otherwise) before the new appointment is made by the President. This can significantly affect the operation and effectiveness of the office, especially where ongoing investigations into possible criminality by PEPs are concerned.

The different approaches perhaps reflect the uncertainty as to the position of the Auditor General. In practice the Constitutions almost invariably provide for a fixed-term appointment to other 'national institutions'. Yet these are largely multimember bodies where a periodic change of membership is inevitable. As the work of the Auditor General 'inherently entails investigation of sensitive and potentially embarrassing affairs of government' including any potential wrongdoing by PEPs, the office-holder is in a very different position from those in other national institutions. ${ }^{68}$ Given this reality, arguably the office-holder must enjoy the same terms and conditions as that of a senior judge. Suitable illustrations come from Nigeria where the position of the Auditor General is similar to that of a judge, i.e. she/he holds office until retiring age ${ }^{69}$ and from Ghana where the Auditor General is appointed until retirement age. ${ }^{70}$

67 article $127(1)$.

68 The same point applies to the appointment of the director of an Anti-Corruption Commission.

69 Section 87(2).

70 article 187(12). 


\section{PART 5: SUPPORTING AND OVERSEEING THE WORK OF THE AUDITOR GENERAL}

The Chiluba case illustrates the failure of an Auditor General to perform his constitutional responsibilities. As noted earlier, the then President of Zambia, Frederick Chiluba and several of his close associates (all PEPs) looted large sums of state money under the guise of national security needs through what was known as the Zamtrop account. During the entire time the criminality was taking place, the Auditor General remained inactive and also failed in his constitutional duty to make annual reports to Parliament. ${ }^{71}$ As Peter Smith J explained in Attorney General for Zambia v Meer Care \& Desai:

Mr Siame, the Auditor General failed properly to exercise his duties or alternatively chose not to exercise the duties required of him probably because of the intimidatory nature of Chungu [Chiluba's national security chief and co-conspirator] and the unwillingness of the Auditor General to challenge him and thus the President. ${ }^{72}$

However, payments though the Zamtrop account were still subject to scrutiny by the Auditor General. Yet, as Peter Smith J noted:

There are provisions for the issue of certificates to the Auditor General on a quarterly basis. I observe that there were indications of audit approvals in the early 1990s but none has been discovered for the period the subject matter of this action...

This highlights the pressure PEPs can exert on Auditors General and emphasises once again the significance of maintaining the independence of the office-holder and his/her staff. It also emphasises the need to ensure that effective 'guarding of the guards' safeguards are in place.

\section{i) The role of parliament}

Reflecting Core Principle 5, i.e. the right and obligation to report on their work, a typical constitutional requirement is for the Auditor General to submit his/her report to the legislature within a specified time period after the end of the preceding

71 See now Constitution of Zambia, article 121(4).

$72 \mathrm{n} \mathrm{10}$. The payments were also facilitated through the bribery of a senior public official in the Ministry of Finance. 
financial year. A specialist multi-party public accounts committee (or equivalent) is then to review the report and may call any Ministers, public officials or others to explain any discrepancies. The annual report may be supplemented by ad hoc reports. The legislature is then required to debate the report of the Auditor General and to make recommendations or give instructions for follow-up action. ${ }^{73}$ For example, article 229(8) of the Constitution of Kenya provides that "within three months after receiving an audit report, Parliament ... shall debate and consider the report and take appropriate action' ${ }^{74}$ Such a provision should be enshrined in every Constitution.

The Chiluba case illustrates the challenge of making such scrutiny effective in practice. The Auditor General was under a constitutional mandate to lay an annual report before parliament but never did so. Parliamentarians failed to pursue this. Thus whilst constitutional safeguards did exist their failure meant that Chiluba and his associates were able to carry out their criminal conspiracy. In essence, through the intimidation or bribery of key public officials their criminality was hidden from view by the failure of the constitutional safeguards. ${ }^{75}$

The extent to which parliamentary scrutiny is effective in practice is questionable. For example, a report published on behalf of the African Parliamentarians Network Against Corruption found that 'too few African parliaments have effective committee systems, and it is rarely possible to properly scrutinise the behaviour of ministers or the senior civil servants who work with them?. ${ }^{76}$ This highlights two potential issues. First, the extent to which the appropriate expertise and experience is available in order for parliamentarians to assess and interpret the reports of the Auditor General. Second, given the reality

73 Core Principles 5-7 recognise (i) the right and obligation of supreme audit authorities to report on their work; (ii) the freedom both to decide the content and timing of audit reports and to publish and disseminate them; and (iii) the need for effective follow-up mechanisms on their recommendations.

74 See for example Constitution of Ghana, article 187(5) and (6) and Constitution of Nigeria, section 85(5). The Constitution of Kenya, article 229(8) provides that "within three months after receiving an audit report, Parliament ... shall debate and consider the report and take appropriate action'.

75 For another glaring example of a failure by a parliamentary committee to address a corruption issue, see Roger Tangri and Andrew Mwenda, 'Politics, Donors and the Ineffectiveness of Anti-Corruption Institutions in Uganda' (2006) 44(1) Journal of Modern African Studies, 101.

76 Joanne Davis Parliamentarians and Corruption in Africa: The Challenge of Leadership and the Practice of Politics (The Parliamentary Centre, Ottawa 2009). 
of executive control over parliamentary business, whether there is the commitment or ability on the part of parliamentarians to do so. ${ }^{77}$

It means that additional support mechanisms are required.

\section{ii) The role of public officials and whistleblowing}

Whilst a discussion on whistleblowing is beyond the scope of this article, a few comments in relation to the Auditor General are appropriate.

The use of whistleblowers is a potentially vital means by which to break through the secrecy surrounding corruption cases involving PEPs. The need for states to develop effective whistleblowing schemes is reflected in article 8(4) of the UNCAC which provides that each State Party must consider:

... [E]stablishing measures and system to facilitate the reporting by public officials of acts of corruption to appropriate authorities, when such acts come to their attention in the performance of their functions.

The Auditor General clearly falls into the category of an 'appropriate authority'. A CoSP resolution also calls on UNCAC States Parties to establish 'measures and systems to facilitate the reporting of incidents' which may be considered to constitute Convention offences. ${ }^{78}$

It is trite that corruption and abuse of office by PEPs requires the assistance or acquiescence of others, both within and outside the public service and information provided by whistleblowers is one of the most common ways in which instances of such criminality are identified. ${ }^{79}$ This emphasises the importance of having in place effective whistleblowing laws and mechanisms which facilitate reporting to an appropriate authority, and in particular, the Auditor General.

Arguably, this includes placing a duty on public officials to report corrupt practices or other misuse of office within the public service. This is clearly contentious, not least because of the dangers this may well pose to the whistleblower and his/her family. The argument for doing so is set out neatly in the Explanatory

\footnotetext{
77 Akech also suggests that key parliamentary committees are themselves implicated in corruption and therefore take no effective steps to address the reports of the Auditor General: see Migai Akech 'Abuse of Power and Corruption in Kenya' (2011) 18(1) Ind J Global Legal Stud 342.

78 UNCAC Conference of States Parties resolution 6/6 of 2015: Follow-up to the Marrakech declaration on the prevention of corruption (2015) para 4.

79 UNODC The United Nations Convention Against Corruption: Resource Guide on Good Practices in the Protection of Reporting Person (2015) 3.
} 
Memorandum to the Council of Europe Code of Conduct for Public Officials which notes that whilst this could create tensions amongst public officials, "the passive or tolerant attitude of public officials regarding breaches would be more harmful for public administration and society as a whole'. ${ }^{80}$

In fact anti-corruption legislation in South Africa already places a duty on any person who holds a 'position of authority' and who 'knows or ought reasonably to have known or suspected that any other person' has committed a serious corruption offence to report the fact to any police official. ${ }^{81}$ This position is potentially complicated by state security legislation which criminalises the unauthorised disclosure of government documents/information. ${ }^{82}$ Given that the Auditor General is specifically authorised to have access to all government documentation, including national security information, there is no reason why such a reporting mechanism is not put in place.

\section{iii) The role of civil society/the media}

Civil society organisations (CSOs) can play both an oversight role and a supportive role.

The oversight role involves the monitoring of the work of the Auditor General. For example, in the Chiluba case the failure of the Auditor General to submit annual reports to the Zambian parliament and the failure of parliamentarians to address the matter represented a fundamental breakdown of the constitutional safeguards. By directing media attention to this situation CSOs would have raised public awareness of this failure and called for an explanation. This provides a 'safe' and constructive role for CSOs in that attention is not being drawn to any allegation of corruption or other wrongdoing by PEPs or a 'cover-up' but merely highlighting the constitutional responsibility of the Auditor General.

Where concern arises regarding a failure to carry out the constitutional mandate, CSOs may also consider lodging a complaint with another constitutional 'watchdog' body. For example, in the Ouko case (see below), the complainant had previously lodged a series of complaints concerning a breach of the constitutional

\footnotetext{
80 para 70.

81 Prevention and Combating of Corrupt Activities Act (No 12 of 2004) section 34. See also section 39(1) Prevention and Combating of Corruption Act 2007 (Tanzania). As suggested above, a requirement to report to the Auditor General would be more appropriate. 82 For example, during his investigation into the corruption by PEPs in Kenya, Justice Bosire specifically referred to the effect of the law and oath of secrecy on silencing public officials: see Republic of Kenya Report of the Judicial Commission of Enquiry into the Goldenberg Affair (2005) 842.
} 
obligations of the Auditor General with the Kenya Ethics and Anti-Corruption Commission. Such a failure arguably also falls within the jurisdiction of the office of the ombudsman (or similar national institution) which has a mandate to investigate complaints of 'maladministration'. ${ }^{83}$

Key supportive work of CSOs includes undertaking public education initiatives to highlight the constitutional role of the Auditor General as the 'ally of the people'. Helping people to understand the constitutional safeguards and focusing attention on their effective operation (or otherwise) can arguably make a real contribution towards developing transparency and accountability in the management of public affairs. In addition, CSOs can play a useful role in assisting parliamentarians to understand and ensure the implementation of the constitutional safeguards with regard to public sector finance. ${ }^{84}$

In order to assess the work of the office, public access to annual reports of the Auditor General is essential. In the TI Kenya case, for example, the petitioner challenged the constitutionality of section 72 of the PAA which recognised the right of public access to such reports 'except where such access may unduly jeopardise state security'. It was argued by the petitioner that any limitation on access to the reports must satisfy the test for the limitation on the enjoyment of rights and fundamental freedoms enshrined in the Constitution. Whilst not deciding the point, Mwita $\mathrm{J}$ noted that any 'limitation on grounds of national security would have to be justified' particularly in view of the right to freedom of information enshrined in article 35 of the Constitution of Kenya. ${ }^{85}$ Thus once published, reports by Auditors General become public documents and it was therefore the constitutional right of every citizen to have access to the document subject to any constitutional rather than statutory limitation.

The role of the courts in supporting CSOs should not be overlooked. This is epitomised by the TI Kenya case in which Transparency International (Kenya) had locus standi (a point seemingly unchallenged) to lodge a petition in support of the

\footnotetext{
83 Although it is not clear in some cases as to whether the jurisdiction of an ombudsman is strictly limited to public officials: as has been noted earlier, the Auditor General is a constitutional office-holder and not a public official.

84 Providing assistance and information to parliamentarians to help ensure that all constitutional safeguards are fully understood is a potentially important role for CSOs: see The Abuja Guidelines on the relationship between Parliaments, Parliamentarians and Commonwealth National Human Rights Institutions (2004) <https://www.agora-parl. org/sites/default/files/guidelines_abujaworkshop.pdf> accessed 3 October 2018.

85 Article 35 provides that 'Every citizen has the right of access to information held by the State' and that 'The State shall publish and publicise any important information affecting the nation'.
} 
independence of the Auditor General. This generous approach to standing should encourage other CSOs to make use of the courts to challenge any threats to the work of Auditors General.

\section{PART 6: REMOVING THE AUDITOR GENERAL}

\section{i) Grounds for removal}

The grounds for removal enshrined in the Constitutions are similar to those of a judge. For example the Constitution of Namibia provides: 'The Auditor General may be removed from office by reason of an 'inability to discharge the functions of his office (whether arising from infirmity of mind or body) or for misconduct'. ${ }^{86}$ Similarly, in South Africa the Auditor General may be removed from office only on the ground of misconduct, incapacity or incompetence. ${ }^{87}$ In Kenya article 251(1) provides that the grounds for removal are a serious violation of the Constitution or any other law; gross misconduct, whether in the performance of the member's or office-holder's functions or otherwise; physical or mental incapacity to perform the functions of office; incompetence; or bankruptcy. Less satisfactory is the position in Nigeria where the Auditor General may be removed from office by the President on grounds of an 'inability to discharge the functions of his office (whether arising from infirmity of mind or body or any other cause) or for misconduct' (emphasis added) ${ }^{88}$

\section{ii) Procedure for removal}

\section{a) Commencing the removal process}

How the removal procedure is commenced requires careful scrutiny as it offers a mechanism to intimidate and/or undermine the Auditor General. This is based on the fact that the Constitutions typically provide that the President may suspend the Auditor General from office after the start of the removal proceedings.

In most of the Constitutions, parliamentarians or a parliamentary committee may commence an investigation. For example, section 184(3) of the Constitution of Malawi provides that the 'Public Appointments Committee may at any time inquire as to the competence of the person so appointed to perform the duties of

\footnotetext{
86 Article 127(4).

87 Section 194(1).

88 Section 87(1).
} 
that office and as to the financial probity of a person so appointed, so far as it is relevant to the duties of that office'.

Who else may request that the possible removal of the Auditor General is rarely elaborated in the Constitutions. The right of an individual to do so was brought into issue in the 2017 decision of the Kenyan High Court in Republic v Speaker of the National Assembly \& 4 others Ex-Parte Edward R.O. Ouko (the Ouko case). ${ }^{89}$ Here article 251(2) of the Constitution of Kenya specifically provided that 'a person desiring the removal of [the Auditor General] on any [relevant] ground may present a petition to the National Assembly setting out the alleged facts constituting that ground'. The National Assembly must then consider the petition and, if it is satisfied that it discloses a ground for removal, must send the petition to the President. The President may then suspend the Auditor General pending the outcome of the complaint.

The case raises several issues of general concern. First, the complaint was submitted to the National Assembly by a petitioner, who was the legal representative of an undisclosed complainant who sought the removal of Mr Ouko. The prospect of a series of such petitions being presented to the National Assembly by any number of anonymous individuals is clearly of practical concern, particularly when dealing with them is liable to distract the Auditor General and can be used by political enemies or disgruntled individuals to undermine the work of the office-holder. In the case itself, the anonymous complainant had made a series of complaints concerning Mr Ouko, some of which fell within the scope of article 251. However, these had already been referred to the Ethics and Anti-Corruption Commission and the Director of Public Prosecutions whose investigations had vindicated Mr Ouko. In essence the petitioner was 'forum shopping'.

Second, the procedure adopted by Parliament was questionable. Here the petitioner was permitted to give unsworn testimony before a parliamentary committee and this was heard without the applicant, Mr Ouko, being given any prior notice of the hearing nor afforded a chance to cross-examine the petitioner. Further the applicant had not been informed of the precise nature of the allegations against him nor given sufficient time to address them. Whilst not disputing the right of parliament to deal with the matter and to regulate its own procedures, the applicant argued that there was procedural unfairness in the manner in which the parliamentary committee approached the matter. Odunga $\mathrm{J}$ upheld this argument pointing out that any such action must be constitutional and lawful. Article 47 of the Constitution of Kenya specifically provided: 'Every person has the right to administrative action .... He therefore held, correctly it is argued, that the article required a court to look both at the merits and legality of an administrative decision

${ }^{89}$ Ouko [2017] eKLR. 
and at the process and procedure adopted. ${ }^{90}$ Further he said even at common law fairness in administrative action was paramount. ${ }^{91}$

This point raises a broader question concerning the separation of powers and the right of the courts to question parliamentary proceedings. The Commonwealth (Latimer House) Principles emphasise: 'Parliamentarians must be able to carry out their legislative and constitutional functions in accordance with the Constitution, free from unlawful interference'. ${ }^{92}$ However, as Odunga J pointed out, the Constitution is supreme and thus Parliament 'cannot enjoy privileges, immunities and powers which are inconsistent with the fundamental rights guaranteed in the Constitution ... Parliamentary privilege does not extend to violation of the Constitution [and where Parliament does so] the Court's jurisdiction would not be defeated....93 In doing so he 'associated himself' with a series of decisions from other Commonwealth jurisdictions ${ }^{94}$ and affirmed the words of Lord Denning in Gouriet v Union of Post Workers noted earlier, 'Be you ever so high, the law is above you'.

Odunga $J$ also addressed an argument by the respondents that the parliamentary committee was exercising an administrative function and not a quasi-judicial function. In his view, the issue for the court was not whether the action was described as 'quasi-judicial' or 'administrative' but rather whether Parliament was 'undertaking an act that affects the legal rights and interests of the applicant to whom the action related' ${ }^{95}$ This was clearly the case here.

As a result, Odunga $J$ issued a declaration that the proceedings conducted by the appropriate parliamentary committee failed to meet the threshold of fair administrative action and ordered that the committee conduct its proceedings in strict compliance with and adherence to Article 47 of the Constitution of Kenya.

90 para 118. In doing so, he referred with approval to the decision of the Constitutional Court of South Africa in Republic of South Africa $v$ South African Rugby Football Union [2000] (1) SA 1 [135]-[136] which applied section 33 of the Constitution of South Africa which was in similar terms to the Kenyan provision.

91 Ibid [79].

92 para III(a).

93 Ibid [81].

94 For example Biti v Minister of Justice, Legal and Parliamentary Affairs [2002] ZWSC 10 (Supreme Court of Zimbabwe); Doctors for Life v Speaker of the National Assembly [2006] (6) SA 416 (Constitutional Court of South Africa).

95 Ibid [112]. In doing so, the judge adopted the words of Lord Denning in Breen $v$ Amalgamated Engineering Union [1971] 2 QB 175 [190] who emphasised that whether functions are described as judicial or quasi-judicial or as administrative the body still must act fairly. 


\section{b) The removal process}

Given the status of the Auditor General and the need to avoid the politicisation of the matter, there is a strong case for the decision regarding removal being a matter for the judiciary. This is the position in Kenya where the President must appoint a judicial tribunal of enquiry which is to investigate the matter 'expeditiously' and must to make a binding recommendation upon which the President must act within thirty days. ${ }^{96}$ In Ghana, the matter is entirely removed from the legislature with the procedure for removal of the Auditor General being the same as that of a senior judge. ${ }^{97}$

Where the removal process involves the legislature, the approach in South Africa provides an important model. This is commenced by a finding by a committee of the National Assembly of misconduct, incapacity or incompetence on the part of the Auditor General. If the National Assembly then adopts by a resolution supported by at least two-thirds of its membership calling for the removal from office of the Auditor General, the President must remove the Auditor General from office. Interestingly, the drafters of the 1996 Constitution provided that the removal process required a simple majority of National Assembly members only. However the Constitutional Court did not consider that this adequately safeguarded that office-holder's independence and impartiality and the constitutional provision was accordingly amended to require a two-thirds majority. ${ }^{98}$ Similarly, in Nigeria, the Auditor General may be removed from office solely by the President 'acting on an address supported by two-thirds majority of the Senate'.

The requirement for a super-majority provides a welcome additional safeguard. However, the concern remains that the weakness of many legislatures and the dominance of the ruling party in many jurisdictions may inevitably result in the politicisation of the removal decision.

\footnotetext{
96 The tribunal must consist of a person who holds or has held office as a judge of a superior court, at least two persons who are qualified to be appointed as High Court judges; and one other member who is qualified to assess the facts in respect of the particular ground for removal: see Article 251(5). It is required to investigate the matter expeditiously, report on the facts and make a binding recommendation to the President, who must act in accordance with the recommendation within thirty days.

97 article 187(13).

98 See Ex parte Chairperson of the Constitutional Assembly: In re Certification of the Constitution of the Republic of South Africa (n 28).
} 


\section{PART 7: CONCLUSION}

The power of PEPs to 'control the controls' facilitates corrupt practices and misuse of public office. The challenge is to prevent the abuse of this power and to protect the good governance values of integrity, transparency and accountability enshrined in constitutions. This article has argued that as the 'ally of the people', the Auditor General can, and must, play a leading role through ensuring fiscal integrity. This has the dual purpose of both encouraging 'ethical behaviour [by PEPs] by making unethical behaviour hard to accomplish and easy to detect' and helping to bring to light any abuse of power. ${ }^{99}$ As Klug neatly puts it, such an independent constitutional institution has 'a distinct role in ensuring that the promises of human rights and good governance [enshrined in the Constitution] reach down into the daily administration of the country.... 100

All the Constitutions noted in this study make provision for the office of the Auditor General and, as the examples from Zambia and Malawi illustrate, an effective Auditor General poses a threat to corrupt PEPs by '[flinging open] the gates to what was meant to be a clandestine and non-detectable criminal syndicate of fraudsters and money launderers'. ${ }^{101}$ Yet the cases of Chiluba and Abacha, for example, highlight the pressure that PEPs can exert on office-holders. Thus the real test is the extent to which, in practice, Auditors General enjoy the necessary individual and institutional independence and security of tenure to enable them to carry out their constitutional mandate effectively. This includes enjoying access to all public expenditure, including that relating to 'national security'. However, this article has demonstrated that several of the Constitutions do not adequately protect the office and the office-holder and that there is a need to strengthen key provisions.

Fundamentally there is a need to review the relationship between the Auditor General and the legislature. Retaining the close working relationship between the two as regards fiscal matters remains essential. This includes the supportive role of the legislature through the appropriate scrutiny and follow-up on annual audit reports. There is also an accountability role for the legislature which must also follow up any failure by the Auditor General to submit such reports. However, given the weakness of many legislatures, their role in the appointment and removal process of the Auditor General raises serious concerns. In most of the jurisdictions under discussion, the present constitutional arrangements arguably do not

99 n 17.

100 Heinz Klug, 'Accountability and the Role of Independent Constitutional Institutions in South Africa's Post-Apartheid Constitutions' (2015-2016) 60 NY Law School Law Review $153,156$.

101 See Republic v Lutepo (n 25) (Kapindu J). 
adequately protect the independence of the office and office-holder in practice. Instead it is argued that the position of the Auditor General should be equated to that of a senior judge including enjoying the same terms and conditions as regards security of tenure and removal.

As an 'ally of the people' the Auditor General requires support from civil society organisations. The article has highlighted a range of opportunities for doing so, such as publicising and monitoring the work of the office. This includes enjoying public access to the reports of the Auditor General. Challenging attempts to undermine its operation is another key measure including, where necessary, resort to the courts. The TI case neatly demonstrates how effective such action can be and should encourage CSOs in other jurisdictions to challenge any attempt to restrict the work of the Auditor General.

To adapt Lord Denning's words 'Be you ever so high, the Constitution is above you'. The Auditor General as a constitutional office-holder has the power to control PEPs and thus uphold the good governance values enshrined in the Constitution. It is hoped that the views expressed in this article will contribute to making this role more effective in practice and truly make the Auditor General the 'ally of the people'. 